Revista Iberoamericana, Vol. LXXIV, Núm. 224, Julio-Septiembre 2008, 635-648

\title{
LA VANGUARDIA SILENCIOSA
}

\author{
POR \\ Rodolfo Mata \\ Universidad Nacional Autónoma de México
}

En la poesía hispanoamericana parece no existir un acontecimiento que señale el "fin de las vanguardias" de una manera emblemática como lo hace el famoso soneto "Tuércele el cuello al cisne...”, con que González Martínez da por terminado el modernismo en 1911. El año clave del inicio de las vanguardias latinoamericanas es, por consenso, 1922, con los reconocidos preámbulos del "Non serviam” de Huidobro y otros textos y eventos, así como el del modernismo es 1898 con la publicación de Azul, aunque con figuras precursoras como José Martí y Manuel Gutiérrez Nájera. El contraste entre modernismo y vanguardia ayuda a establecer un cuadro más o menos estable y un territorio intermedio que ha recibido diversas denominaciones: posmodernismo, modernismo tardío, intimismo, etc. Sin embargo, no se ha establecido un contraste similar entre las vanguardias y un nuevo elemento periodizador, en principio porque no hay consenso acerca de cuál sería dicho elemento, ni qué características tendría, o si en realidad no se trata de un solo elemento, sino de varios, que pudieran o no ser descritos mediante alguna categoría que los englobara. Se conoce la diversidad de la vanguardia, sus temáticas y actitudes principales, algunas corrientes que la atraviesan como la poesía pura, el "surrealismo tardío” y el viraje significativo hacia el compromiso social y político, pero se ha escrito poco acerca de su fin o sus transformaciones definitivas y diferenciadoras.

Una de las propuestas sobre las mutaciones de la vanguardia es la que hace Octavio Paz en Los hijos del limo; del romanticismo a la vanguardia donde afirma que "hacia 1945 la poesía de nuestra lengua se repartía en dos academias: la del 'realismo socialista' y la de los vanguardistas arrepentidos”. Paz señala que, en ese contexto, algunos autores y sus obras iniciaron un cambio que en cierto sentido fue un regreso a la vanguardia, pero una vanguardia silenciosa, secreta, desengañada, crítica de sí misma y en rebelión solitaria contra la academia en que se había transformado la primera vanguardia. El principal interés de esta vanguardia ya no era "inventar" sino "explorar" pues "el territorio que atraía a estos poetas no estaba afuera ni tampoco adentro. Era esa zona donde confluyen lo interior y lo exterior: la zona del lenguaje”. Entre los autores y obras que Paz enumera como iniciadores de este cambio están José Lezama Lima, Enrique Molina, Nicanor Parra, Alberto Girri, Jaime Sabines, Cintio Vitier, Roberto Juarroz y Álvaro Mutis. De los dos primeros señala 
los libros La fijeza (1944) ${ }^{1}$ y Costumbres errantes o la redondez de la tierra (1951), y de su propia obra menciona Libertad bajo palabra (1949) y ¿Águila o sol? (1950). En el presente ensayo se hará la revisión de estas coordenadas complementando su análisis con lo que, en Los hijos del limo, Paz llama “poesía de la posvanguardia” y que confluye con algunas reflexiones suyas posteriores.

BREVE REVISIÓN CRONOLÓGICA Y TERMINOLÓGICA

Uno de los primeros trabajos de revisión de las fechas y términos utilizados para definir la vanguardia latinoamericana es "Latin American Vanguardismo: Chronology and Terminology” de Merlin H. Forster (12-50). Como mencioné al principio, los datos recogidos por Forster confirman que existe una mucho más clara problematización acerca del inicio del vanguardismo, aunque haya discrepancias acerca de los criterios utilizados para ubicar el cierre del modernismo hispanoamericano o del parnasianismo brasileño. En cambio, su final es mucho más vago. Forster hace una amplia cita de Mariano Picón Salas y coincide con él en dividir al vanguardismo latinoamericano en dos períodos: de 1920 a 1930, período iconoclasta de grandes cuestionamientos, revistas, manifiestos y proliferación terminológica que buscan identificar la sensación de novedad y exuberancia característica de esos años; y de 1930 a principios de los cuarenta, que identifica como un período de madurez relativa e impaciencia con algunas de las soluciones más aclamadas. Más adelante puntualiza que lo más frecuente es situar el cierre del vanguardismo al final de la segunda guerra mundial y usar términos que sugieren tanto una continuidad como una reacción contra el período que lo antecede. Por ejemplo, pós-modernismo es usado ampliamente en la crítica brasileña mientras el término más frecuente en Hispanoamérica es posvanguardismo. De nuevo, las reacciones e incertidumbres de un período de posguerra parecen legitimar esta relación, especialmente si se la vincula con el florecimiento de una nueva y articulada generación en todos los centros de actividad literaria. Según el autor, esta agrupación posvanguardista estaría caracterizada entonces por figuras como Octavio Paz, José Lezama Lima, Nicanor Parra, Julio Cortázar, João Guimarães Rosa y João Cabral de Melo Neto (17-8). Forster explica que algunos críticos como Eugenio Florit hacen comenzar el posvanguardismo en 1930 e incluyen a figuras como Neruda, Vallejo y Borges, en un primer grupo, y en un segundo grupo a Paz y a Parra.

De igual manera, Nelson Osorio, en su "Prólogo" a Manifiestos, proclamas y polémicas de la vanguardia literaria hispanoamericana, hace un detallado análisis de la transición modernismo-vanguardia durante el segundo decenio del siglo xx. ${ }^{2}$ Insiste en los vínculos entre el proceso económico-social de modernización y la producción artística, y señala

1 Es importante notar que Paz da esta fecha aunque realmente La fijeza fue publicado en La Habana por la editorial Orígenes en 1949. La revista Orígenes, dirigida por Lezama Lima y José Rodríguez Feo, sí comenzó a publicarse en 1944 y concluyó en 1956. El error no fue corregido en las Obras completas 1. La fecha de 1949 aproxima esta obra a Libertad bajo palabra (1949).

2 Osorio identifica en este período tres promociones poéticas: 1) los modernistas consagrados (como Lugones y Nervo); 2) los modernistas crepusculares, que subdivide en dos grupos: aquellos que permanecieron fieles a la estética modernista, con ligeros cambios como la incorporación de elementos religiosos, panteístas u orientalistas (por ejemplo, Gabriela Mistral), y los que buscan articular su 
factores que son comunes al fin de la hegemonía del modernismo y al vanguardismo: las condiciones económicas creadas por la primera guerra mundial; la incorporación de América Latina al capitalismo internacional con un avance significativo de la influencia de Estados Unidos en la región; los problemas surgidos del imperialismo y los monopolios; crisis en el comercio exterior que dispara un incipiente proceso de sustitución de importaciones; fortalecimiento de las burguesías locales y de los sectores más dinámicos (banca, industria, comercio y comunicaciones) con la participación del Estado; crecimiento de las ciudades, las capas medias urbanas y el proletariado; debilitamiento de las oligarquías agrarias por el receso de las exportaciones; mayor conciencia de pertenecer a una comunidad histórica, lo cual da un valor positivo a las diversidades nacionales y regionales; incremento en la participación política de las masas; aparición de movimientos antioligárquicos y reformistas, olas de populismo -honesto o demagógico- y movimientos de reforma universitaria que enfatizan los valores populares, las necesidades nacionales y la transformación social, en los que se percibe la alianza de los sectores estudiantiles (provenientes en gran parte de las clases medias, según Mariátegui en proceso de proletarización) con los trabajadores.

Estos factores actúan, según Osorio, desde el inicio de la primera guerra mundial en 1914 hasta principios de los años treinta, y coinciden con los triunfos de Hipólito Yrigoyen en Argentina (1916), Arturo Alessandri en Chile (1920), Augusto B. Leguía en Perú (1919), y la caída del dictador Manuel Estrada Cabrera en Guatemala (1920). Sin embargo, el crack bursátil neoyorquino de 1929 inicia una crisis que provocará una baja brutal en las exportaciones de América Latina y estará relacionada con varios golpes de Estado, sublevaciones y conflictos diversos. Osorio lo explica señalando la existencia de una nueva alianza entre las burguesías y las oligarquías locales que, para defender el sistema amenazado por la crisis y consolidar su dominio, recurren al golpe militar y a la represión interna. En vísperas de la segunda guerra mundial, subraya Osorio, la gran mayoría de los países latinoamericanos vivía bajo gobiernos militares. Estos gobiernos transforman el espacio de tal manera que quedan pocas posibilidades para los polémicos desplantes de los vanguardistas.

Nelson Osorio llega a la conclusión de que existen dos períodos de la vanguardia latinoamericana. El primero se traslapa con el ocaso del modernismo y coincide con el impulso renovador que se extiende del principio de la primera guerra mundial, en 1914, hasta 1930, año en que dicho impulso es liquidado tanto por causas internas como por los efectos de la crisis económica internacional que surge en 1929. El segundo va de 1930 al comienzo de la segunda guerra mundial y coincide con el ascenso de gobiernos militares en América Latina. Osorio no analiza detalladamente este período ni incluye textos de él en su antología, porque explica que amerita un estudio aparte. No obstante, el soporte de su descripción del proceso económico-social de la región, además de dar una mayor profundidad a la tipificación de la primera etapa-señalada por Forster como una etapa más experimental, agresiva y polémica- establece un punto de inflexión con la segunda y abre la posibilidad para una explicación del surgimiento de las vanguardias con compromiso social.

obra a las nuevas propuestas (por ejemplo, Regino Boti con su libro Kodak-Ensueño [1929]); y 3) los que comienzan a balbucear las primeras notas de lo que será el vanguardismo (como Vicente Huidobro en sus inicios), promueven la discusión de los manifiestos de Marinetti, y cuestionan el modernismo desde dentro del modernismo, con intenciones más de reformismo que de ruptura. 
Jorge Schwartz, en su "Introducción” a Las vanguardias latinoamericanas: textos programáticos y críticos, revisa el problema de la periodización en un apartado especial. Comenta las fechas de inicio y término de Osorio, junto con las ofrecidas por Hugo Verani y Federico Schopf, y propone como evento inaugural del vanguardismo la lectura pública del manifiesto "Non serviam" realizada por Vicente Huidobro en $1914 .^{3}$ Una alternativa posterior es ubicar este comienzo en el annus mirabilis de 1922, asíllamado por Hugo Verani por la concentración de eventos vanguardistas que guarda esta fecha. Schwartz coincide con Forster y Osorio en señalar el fin de un primer vanguardismo “más experimental” entre 1930 y 1931, y el comienzo de otro con preocupaciones ideológicas, que aparece acompañado por la crisis económica iniciada en 1929 y por el ascenso de gobiernos militares, como lo propone Osorio. El fin de este segundo período, según Schwartz, lo marcan la consolidación del fascismo y la eclosión de la guerra civil española en 1936, eventos que llevan a los intelectuales latinoamericanos a cuestionar el sentido y el compromiso ideológico del arte. Como “cierre del ciclo cronológico" de las vanguardias, Schwartz propone la polémica que levantó el manifiesto "Por un arte revolucionario independiente", lanzado en 1938 por André Breton y Diego Rivera, el cual es criticado duramente por Borges, quien señala el callejón sin salida de las renovaciones del arte a través de este tipo de documentos autoritarios y las contradicciones de los vínculos entre el arte y la política en su artículo "Un caudaloso manifiesto de Breton”.

\section{LA VANGUARDIA SILENCIOSA Y LA POESÍA DE CONVERGENCIA}

En Los hijos del limo, Paz expone su famosa propuesta en que define a la modernidad como “tradición de la ruptura” o "pasión crítica” y la identifica con dos principios en constante enfrentamiento: la analogía y la ironía. La analogía tiene un carácter unificador que establece correspondencias, concilia oposiciones y proyecta la experiencia hacia un ámbito religioso atemporal o vinculado al tiempo cíclico, mientras que la ironía corresponde a la conciencia de la historicidad, la voluntad de lo fragmentario, sucesivo e irrepetible. Al cruzar el umbral representado por la obra de Mallarmé, esta relación dialéctica entre la analogía y la ironía entra en un estado de convivencia paradójico al que Paz llama metaironía: "una suerte de suspensión del ánimo, un más allá de la afirmación y la negación” (156), que en gran parte es el resultado del nacimiento del poema crítico, el poema que reflexiona sobre el acto de escribir. Paz ya lo había definido en El arco y la lira de la siguiente manera:

\footnotetext{
La poesía, concebida por Mallarmé como la única posibilidad de identificación del lenguaje con lo absoluto, de ser el absoluto, se niega a sí misma cada vez que se realiza en un poema (ningún acto, inclusive un acto puro e hipotético: sin autor, tiempo ni lugar, abolirá el azar) salvo si el poema es simultáneamente crítica de esa tentativa. (271)
}

El poema crítico introduce la conciencia de la centralidad del lenguaje como representación en el quehacer poético y prepara el terreno para la aparición de la vanguardia.

3 Las fechas que Schwartz comenta y de las cuales ofrece la referencia son: para Hugo Verani 19161935; y para Federico Schopf se dan dos perspectivas: una como teoría y práctica del vanguardismo, en sentido amplio, 1916-1939; y otra en el sentido restringido de su predominio, 1922-1935. 
Según Paz, la vanguardia es "la gran ruptura y con ella se cierra la tradición de la ruptura” (Hijos 148). Es “una exasperación y una exageración de las tendencias que la precedieron”, "una intensificación de la estética del cambio inaugurada por el romanticismo" (161) que conduce al arte moderno a una esclerosis, principalmente en tres aspectos: 1) en su carácter antagonista, es decir, en los ímpetus con los cuales la vanguardia siempre buscó un enemigo contra el cual luchar, ya sea el público burgués, la academia o cualquier otra instancia; 2) en su confianza en el cambio como sinónimo de progreso que va de la mano de una fe en el futuro; y 3) en su énfasis en la novedad y originalidad de la creación. Dice Paz:

Hoy somos testigos de otra mutación: el arte moderno comienza a perder sus poderes de negación. Desde hace años sus negaciones son repeticiones rituales: la rebeldía convertida en procedimiento, la crítica en retórica, la transgresión en ceremonia. La negación ha dejado de ser creadora. (211)

Esto se debe principalmente a que la burguesía, el enemigo central al que la vanguardia dirigió sus ataques, terminó no sólo aceptando y consagrando sus creaciones sino exigiendo, ya por el lado de un mercado artístico, la continua innovación, desvirtuándola. También contribuyó el hecho de que la institución, la cultura “oficial”, fue sustituida por un relativismo intelectual resultado de la explosión de las vanguardias. Esto propició lo que Hans Magnus Enzensberger llamó “inmunidad crítica”, es decir, el derecho a la legitimación artística por el simple hecho de ser contestatario y perseguido (152).

La misma relativización se dio en el tiempo. El reclamo de todas y cada una de las vanguardias de estar en el punto de avanzada no trajo sino una desorientación. No hay criterio para opinar sobre ello y para decir si el movimiento avanza, retrocede, va hacia el futuro, en fin, si tiene o no un comportamiento teleológico. Hay movimiento pero es un movimiento fluctuante, emparentado con la oscilación browniana y con la stasis (Calinescu 146-7) que en cierta forma es anunciada por la metaironía paciana. A este respecto, Paz dice:

El fin de la modernidad, el ocaso del futuro, se manifiesta en el arte y la poesía como una aceleración que disuelve tanto la noción de futuro como la de cambio. El futuro se convierte instantáneamente en pasado; los cambios son tan rápidos que producen la sensación de inmovilidad. (221)

Ahora, el agotamiento de la elite de avant-garde no hizo sino crear toda una legión de epígonos que se dedicaron sólo a repetir, traicionando así uno de los principales dictados de la vanguardia: la innovación. Cito a Paz:

En realidad no son cambios: son variaciones de los modelos anteriores. [...] A la falsa celeridad hay que añadir la proliferación: no sólo las vanguardias mueren apenas nacen, sino que se extienden como fungosidades. La diversidad se resuelve en unidad. Fragmentación de la vanguardia en cientos de movimientos idénticos: en el hormiguero se anulan las diferencias. (222)

Paz identifica el inicio de la vanguardia en castellano con la aparición de Ecuatorial y Poemas árticos de Huidobro en 1918. El surgimiento de la "vanguardia silenciosa, 
secreta y desengañada” en 1945 puede ser considerado como una disolución parcial de la vanguardia, una transformación significativa, pues Paz conserva la designación, aunque sea adjetivada, y se refiere de la siguiente manera a la posvanguardia: "La poesía de la posvanguardia (no sé si haya que resignarse a este nombre no muy exacto que empiezan a darnos algunos críticos) nació como una rebelión silenciosa de hombres aislados. Empezó como un cambio insensible que, diez años después, se reveló irreversible” (210). Esto quiere decir que aunque gran parte de las características originales de la vanguardia desaparezcan, hay otras que permanecen. De ahí que la vanguardia silenciosa sea en cierto sentido, dice Paz, un regreso a la vanguardia. Veamos.

Paz dice que no se trataba de inventar como en 1920 sino de explorar el territorio del lenguaje, que no se encuentra ni afuera ni adentro, sino en la confluencia de lo interior con lo exterior. Se puede considerar que esa exploración equivale a lo que en la terminología crítica se ha llamado "experimentalismo”. De esta manera, la vanguardia que Paz propone es silenciosa y secreta, como puede ser la actividad del poeta que reproduce una actitud de vanguardia dentro de sí mismo, desdoblándose y volviéndose otro -para usar la propia terminología de Paz-, en un ciclo continuo de "desaprendizaje-aprendizaje”, caracterizado por el autor, más tarde, en La otra voz: poesía y fin de siglo de la siguiente manera:

Cada nueva obra poética desafía a la comprensión y al gusto del público; para gozarla, el lector debe aprender su vocabulario y asimilar su sintaxis. La operación consiste en un desaprendizaje de lo conocido y un aprendizaje de lo nuevo; el desaprendizaje-aprendizaje implica una renovación íntima, un cambio de sensibilidad y de visión. (86-7)

En esta lucha contra símismo, el poeta realiza su trabajo sin alardes, escándalos o posturas autoritarias. No actúa colectivamente ni se presenta a la sociedad como integrante de un grupo que se coloca tras un manifiesto que defiende a ultranza. Sale así de la institucionalización y de la posibilidad de él mismo volverse institución.

Sin embargo, los poetas no dejan de proponer teorías que podríamos entender como poéticas individuales y al mismo tiempo, susceptibles de ser imitadas o seguidas, ni abandonan totalmente el ropaje de los manifiestos y los ismos: los interiorizan. La idea de que la poesía no está "ni afuera ni adentro, sino en la confluencia de lo interior con lo exterior" podría figurar en un manifiesto. De hecho, en el "Prefacio" a Los hijos del limo, Paz asume que ha practicado el género, pues comenta que las últimas páginas de su libro están dedicadas al tema de la vanguardia y se unen a "Los signos en rotación, una suerte de manifiesto que publiqué en 1965 y que ha sido incorporado como epílogo a El arco y la lira” (11). La puesta en práctica de varios de sus postulados se concreta en 1968, con la publicación de Blanco, Topoemas y Discos visuales, que juegan con los “signos en rotación”, y en 1970 se expande con la ejecución del poema colectivo Renga, publicado en 1972. Algo parecido se puede plantear acerca de la “poesía vertical” de Roberto Juarroz. ¿Puede ser vista como una especie de ismo, un "verticalismo" tan personal quizá como el creacionismo de Huidobro, aunque el poeta chileno haya intentado, con todas sus fuerzas, que no lo fuera y se convirtiera en un movimiento caudaloso como el futurismo o el surrealismo, mientras que el argentino haya preferido permanecer en el secreto y el silencio? ¿La antipoesía de Nicanor Parra no podría abordarse desde una perspectiva similar? 
La cuestión del desengaño-recordemos que se trata de "vanguardia silenciosa, secreta y desengañada”- tiene que ver tanto con el anquilosamiento de las dos academias, la del "realismo socialista" y la de los "vanguardistas arrepentidos" -que regresaron a escribir sonetos y décimas- como con el fracaso de los republicanos en la Guerra Civil española y la desilusión ante la ortodoxia atropellante del estalinismo, según Paz afirma. Las primeras páginas del capítulo "El ocaso de la vanguardia” de Los hijos del limo están dedicadas a hacer la comparación crítica entre la política y la religión como vehículos de dogmas. Por ello, en la definición de sus compañeros de generación, Paz afirma: "Sabían asimismo que con ellos no comenzaba el mundo [como había sucedido con algunas actitudes inaugurales de la vanguardia], pero no sabían si no se acabaría con ellos: habían atravesado el nazismo, el estalinismo y las explosiones atómicas en el Japón” (209). Las perspectivas del futuro se habían opacado y las utopías desmoronado. Paz menciona otros rasgos que enumero sucintamente: estaban distanciados de los poetas españoles de la posguerra, pues éstos se demoraban en la poesía social o en la religiosa; sentían atracción por el surrealismo ya en repliegue; veían a los poetas angloamericanos posteriores al modernism -Lowell, Olson, Bishop, Ginsberg- como sus pares; descubrieron a Pessoa y a los brasileños como João Cabral de Melo Neto; y sentían horror hacia la civilización de occidente, y atracción por el oriente, los primitivos o la América precolombina.

Los esfuerzos críticos de Paz en Los hijos del limo y La otra voz no tienen como destino final la definición de las diferencias entre su generación y la anterior, sino que avanzan un poco más para delinear las características de la poesía en el momento en que dichos libros fueron escritos. De esta manera, desde la última sección de Los hijos del limo, titulada "El punto de convergencia”, Paz comienza a dibujar el panorama cultural que sirve de escenario a estas transformaciones. Ya inclui parte de este panorama en los comentarios que hice acerca del agotamiento de las vanguardias y sobre el experimentalismo, y ahora lo complemento glosando a Paz. La pérdida de la fe en el futuro no aparece sólo ligada a la cuestión del desengaño político y la autodestrucción atómica, sino también al agotamiento de los recursos naturales y a los problemas de contaminación. Paz señala que si antes se veneraba el cambio ahora lo que se busca es la conservación. A la vez que la idea de la historia como un proceso lineal y progresivo ha cedido ante la de una pluralidad de historias, las pretensiones sobre la dirección del futuro se han disuelto. Paz cita el concepto de sociedad posindustrial de Daniel Bell y lo conecta con la posibilidad de que la rebelión estudiantil de los años sesenta obedezca a la excesiva racionalización de la vida social e individual exigidas por los modos de producción, y señala la confianza en los poderes de la espontaneidad, el hedonismo y la imaginación, por encima de la ética protestante y capitalista, con su moral del ahorro y el trabajo, y sus construcciones sistemáticas. De esta manera el rechazo de un presente opresivo, que se aceptaba en aras de un futuro quimérico, lleva a la búsqueda de otro presente, el verdadero. Se trata del ahora, centro de convergencia de todos los tiempos, que originalmente fue visión de los poetas. Paz regresa a la estética del instante y la otredad, y a la concepción de la obra de arte como mediación que ya había propuesto en El arco y la lira.

La diferencia estriba en que en vez de insistir en la importancia del mito, el origen, lo sagrado y la revelación, subraya la crisis de la noción de obra y de autor. De la primera toma como ejemplo más radical los ready-made de Duchamp: "lo que cuenta no es el 
objeto sino el acto del artista al separarlo de su contexto y colocarlo en el pedestal de la antigua obra de arte” (222). De la segunda, menciona como antecedentes la importancia que los surrealistas dieron al inconsciente y al azar, y como ejemplo contemporáneo, en que se subrayan las nociones de permutación y combinación, el poema colectivo Renga -que compuso en 1970 con Jacques Roubaud, Charles Thomlinson y Edoardo Sanguinetisobre el que afirma: "El poeta no es el 'autor' en el sentido tradicional de la palabra, sino un momento de convergencia de las distintas voces que confluyen en el texto" (223, énfasis mío). La noción burguesa del autor se desmorona. "El poeta no es un 'pequeño dios', como quería Huidobro. El poeta desaparece detrás de su voz, una voz que es suya porque es la voz del lenguaje, la voz de nadie y de todos. Cualquiera que sea el nombre que le demos a esa voz -inspiración, inconsciente, azar, accidente, revelación-, es siempre la voz de la otredad” (223). Esta última aseveración es importante porque repite y esclarece el comentario acerca de la relación de la vanguardia silenciosa con el lenguaje -“Estos poetas habían aprendido a reflexionar y a burlarse de sí mismos: sabían que el poeta es el instrumento del lenguaje” (209)- aunque termine fusionándola con la concepción más romántico-surrealista que aparece en El arco y la lira.

La atención al lenguaje se desarrolla en las últimas páginas de “El punto de convergencia”. Paz observa: "Esto es lo que hoy ocurre. Los poetas de la edad moderna buscaron el principio del cambio: los poetas de la edad que comienza buscamos ese principio invariante que es el fundamento de los cambios” (224). Es verdad que el carácter poético del discurso ensayístico de Paz y la utilización que hace de las paradojas plantea dificultades en el momento de validar las interpretaciones que se hacen de él. No obstante, no creo exagerar al proponer que el principio invariante al que se refiere era, en el momento en que escribió Los hijos del limo y desde el punto de vista del lenguaje, la idea de estructura, ya que inmediatamente después Paz reflexiona sobre su lugar en los procesos de escritura y lectura:

Mientras escribe, el poeta no sabe cómo serásu poema; lo sabrá cuando lo haya terminado, lolea. El autor es el primer lector de su poema y con su lectura se inicia una serie de interpretaciones y recreaciones. Cada lectura produce un poema distinto. [...] Soberanía del texto sobre su autor-lector y sus lectores sucesivos. El texto permanece, resiste a los cambios de cada lectura. Resiste a la historia. [...] El poema es un texto, pero asimismo es una estructura. El texto reposa en la estructura -su soporte. El texto es visible, legible; el esqueleto es invisible. [...] Un soneto de Góngora tiene la misma estructura que uno de Quevedo y cada uno de ellos es un mundo aparte. Cada texto actualiza ciertas estructuras virtuales comunes a todos los poemas -y cada texto es una excepción y, con frecuencia, una transgresión de esas estructuras. [...] La estructura es ahistórica; el texto es historia, está fechado. De la estructura al texto y del texto a la lectura: dialéctica del cambio y de la identidad. La estructura es invariante en relación con el texto, pero el texto es invariante en relación con la lectura. (225-6)

Paz prefiere utilizar la palabra “convergencia” a “trascendencia” para designar el encuentro entre lo histórico y lo ahistórico que se produce durante la lectura de un texto poético (leer un texto no poético es comprenderlo; leer uno poético es re-producirlo), y concluye: "La poesía que comienza ahora, sin comenzar, busca la intersección de los tiempos, el punto de convergencia. Afirma que entre el pasado abigarrado y el futuro deshabitado, la poesía es el presente” (227). 
En La otra voz, Paz incluye varios ensayos, pero en ninguno de ellos vuelve a mencionar a la vanguardia silenciosa, a pesar de que en el titulado "Ruptura y convergencia” figura el apartado "Modernidad y vanguardia”. En el siguiente apartado, que se titula "Poesía de convergencia”, critica el término "posmodernidad", tanto porque permanece atrapado en la concepción lineal del tiempo y el progreso de la modernidad, como por su procedencia del modernism anglosajón, que ignora la designación correspondiente usada en Hispanoamérica -vanguardia- y su antecedente: el modernismo rubendariano. Se entiende entonces que la idea del fin de la modernidad, según Paz, esté mejor representada por la poesía de la convergencia, de la coexistencia de diversos tiempos y lugares invocados en el acto de la lectura de poesía, que escapa de la linealidad. Otro tema que aparece y complementa el entorno es la presencia del mercado: "Hoy las artes y la literatura se exponen a un peligro distinto: no las amenaza una doctrina o un partido político omnisciente sino un proceso económico sin rostro, sin alma y sin dirección” (125). La filiación romántica de Paz -que viene del surrealismo y los poetas románticos alemanes e ingleses-se manifiesta al considerar que el arte es “víctima” y, en otras ocasiones, “antídoto de la técnica y del mercado” (138). Este proceso se refleja en los best-sellers, en los estereotipos y obras eclécticas que se promueven tras designaciones como "posmodernismo", y que señalan "la transformación del antiguo comercio literario y artístico en un moderno mercado financiero” (104).

Una de las preocupaciones centrales en Los hijos del limo es describir "el ocaso de las vanguardias”, como lo anuncia el título de su último capítulo. Para ello, Paz se ve forzado a esbozar qué viene después de ese ocaso y qué lo precipita. La "vanguardia silenciosa” aparece como un punto de inflexión, pues una vez que enumera a quienes la integran, el autor agrega: "Estos nombres y estos libros no son toda la poesía hispanoamericana contemporánea: son su comienzo. Hablar de lo que ha seguido, por más valioso que sea, sería caer en la crónica” (208). Más adelante, Paz esboza sus ideas acerca del "arte de la convergencia”, que complementa en La otra voz. Sin embargo, no hay nada que asegure que la vanguardia silenciosa -que también llama posvanguardia-coincida con la poesía de convergencia, entronque con ella o sean dos cosas diferentes. Mientras en Los hijos del limo el énfasis está en la relación del poeta con el lenguaje, en La otra voz se encuentra en la visión del cambio y el tiempo. Hay varios indicios que permiten pensar que hay una diferencia entre la vanguardia silenciosa y la poesía de convergencia, como el que Paz considere que la poesía de convergencia comienza en este fin de siglo (54), o el que recuerde sus batallas contra el realismo socialista y la literatura comprometida como asuntos del pasado (presentes en su caracterización de la vanguardia silenciosa) y señale que el peligro para las artes y la literatura ha pasado de ser una doctrina o un partido político a ser un proceso económico (125). Los criterios seguidos en las antologías también apuntan hacia esta separación. En Poesía en movimiento: México 1915-1966, Paz aparece ubicado en el grupo de poetas anterior al más reciente, y al comentar la Antología de la poesía hispanoamericana contemporánea (1914-1970) de José Olivio Jiménez en su ensayo “Poesía e historia: Laurel y nosotros” (1982), concuerda con este crítico cubano en que para darle continuidad a su trabajo (la selección de Jiménez termina con Nicanor Parra y Octavio Paz, ambos nacidos en 1914), habría por lo menos que atender a una o dos promociones poéticas posteriores que merecían ser antologadas (771-2). Paz podría formar parte de 
la vanguardia silenciosa y practicar la poesía de convergencia sólo si esta última es una condición a la que arribó el quehacer poético en general.

LA VANGUARDIA SILENCIOSA COMO ESBOZO DE UN PROYECTO ANTOLÓGICO

En el brillante ensayo “Tres antologías: la formulación del canon”, Anthony Stanton revisa el papel que han tenido la Antología de la poesía mexicana moderna (1928), Laurel: antología de la poesía moderna en lengua española (1941) y Poesía en movimiento: México 1915-1966 (1966) -prologadas por Jorge Cuesta, Xavier Villaurrutia y Octavio Paz, respectivamente- en la conformación del panorama de la poesía mexicana moderna. ${ }^{4}$ Una de las conclusiones más importantes a las que llega es que si Cuesta y Villaurrutia tenían una visión del cambio de escuelas, movimientos y estilos que mantenía la secreta permanencia de la poesía como esencia inmutable, para Paz la tradición era la aceleración y repetición de los cambios, la "tradición de la ruptura” (53). Stanton señala que Paz, en su ensayo "Laurel y la poesía moderna”, declara tácitamente que no es un poeta de Laurel y que esta antología es la "última expresión del gusto poético predominante entre 1920 y 1945”. ${ }^{5}$ La relación ambigua que muestra Paz, de identificación y extrañeza, con la idea de tradición que subyace en el libro, dice Stanton, encontrará su expresión más plena en Poesía en movimiento, "una visión más coherente y más parcial de la tradición moderna a partir de la vanguardia” que, entre otras cosas, suprime a Enrique González Martínez, prototipo de las prolongaciones del modernismo (52).

Como toda antología elaborada colectivamente es producto de un consenso, observa Stanton, hay incongruencias entre el “Prólogo” de Pazy la selección, realizada en colaboración con Alí Chumacero, José Emilio Pacheco y Homero Aridjis. Stanton comenta la reseña de Paz acerca de los conflictos que hubo en torno a la noción inasible de la tradición de la ruptura y el criterio exclusivista de antologar sólo a los poetas del cambio y la innovación. Pacheco y Chumacero querían tomar en cuenta factores más amplios y nada vanguardistas, como la dignidad estética, el decoro y la perfección, mientras que Paz y Aridjis adoptaron una postura más rígida y parcial. A despecho del resultado ecléctico, advierte Paz, se puede percibir una corriente que empieza en Tablada, atraviesa dos promociones poéticas manifestándose en la obra de algunas figuras y culmina animando a la mayoría de los nuevos poetas (8-9). Esto nos hace ver que Paz, además de ubicarse más tarde dentro de la vanguardia silenciosa, consideraba que la parte viva de la tradición mexicana que había que preservar era la vanguardista-experimental. Si esto era válido para el momento en que se realizó Poesía en movimiento (que el propio Paz califica no de "antología” sino de “experimento”), continúa reflejándose en las secciones dedicadas a la poesía en la revista

${ }^{4}$ En la selección de la primera intervinieron Jorge Cuesta, Enrique González Rojo, Jaime Torres Bodet y Xavier Villaurrutia; en la segunda Emilio Prados, Juan Gil Albert, Xavier Villaurrutia y Octavio Paz; y en la tercera Octavio Paz, Alí Chumacero, José Emilio Pacheco y Homero Aridjis. En su análisis, Stanton traza comparaciones e interrelaciones con tres antologías más: Diego, Onís y Zaid.

5 Stanton cita el ensayo con ese título pero en el volumen Obras completas II que utilizo aparece como "Poesía e historia: Laurel y nosotros". 
Plural, cuando estuvo bajo la dirección de Paz durante los años previos a la publicación de Los hijos del limo. ${ }^{6}$

Asimismo, Stanton subraya que el "Prólogo" a Poesía en movimiento está animado también por la idea de la obra abierta de Umberto Eco, noción muy ligada, aclara, "al renacimiento de una vanguardia experimental en los años sesenta (la poesía concreta, las tendencias plásticas conocidas como op art y pop art, la música aleatoria de John Cage...)” (55). Esto revela el origen de la reflexión que Paz hace acerca de las relaciones entre lectura, texto y estructura -comentada en párrafos anteriores-a propósito del "principio invariante que es el fundamento de los cambios”, el cual, según el autor, es buscado por los poetas después del agotamiento de la modernidad. Una de las precisiones que Paz hace respecto a la obra abierta es la siguiente:

En cierto sentido poesía moderna y obra abierta son términos equivalentes. Desde esta perspectiva el iniciador del movimiento, en lengua española, es Vicente Huidobro. Pero la verdadera obra abierta, en sus expresiones más rigurosas y complejas, es reciente. La prefiguran ciertos textos de Macedonio Fernández y aparece plenamente en algunos poemas y novelas de unos cuantos poetas y escritores de mi generación. Pienso en Rayuela, de Julio Cortázar, y en la poesía de un autor menos conocido, el cubano José Lezama Lima. (11-2) ${ }^{7}$

Paz complementa su observación proponiendo que lo que distingue a su generación de la de Borges y Neruda es la concepción del lenguaje y de la obra. Si Neruda tiene confianza en los significados (pone a prueba las palabras en un purgatorio de sensaciones y pasiones) y Borges, en dirección contraria, muestra el revés del significado (provoca el cambio de orientación o la desaparición del sentido), las palabras se salvan. En uno u otro caso el lector acepta o rechaza. En cambio, en su generación, Cortázar plantea Rayuela (1963) como una invitación a jugar a escribir una novela, haciendo que el lector no sólo participe sino que intervenga. Lezama Lima, aclara, se despliega en otra dirección:

Se ha dicho que sus poemas son informes. Creo lo contrario: son un océano de formas, un caldo criollo en el que nadan todas las criaturas terrestres y marinas del lenguaje español, todas las hablas, todos los estilos. Ese hervidero de formas seduce y aterra. Lezama ensancha los límites de la obra y pone a la disposición del lector no un libro sino lo que sobrevive de los libros. En suma, los poetas de la generación anterior usaron y abusaron de una propiedad

6 Plural estuvo bajo la dirección de Paz a partir de su fundación, en octubre de 1971, hasta julio de 1976. La veta vanguardista se puede ver, por ejemplo, en el número 5, de febrero de 1972, donde se incluye una sección titulada "Escritura visual” en que participan, entre otros, John Cage, Guillermo Cabrera Infante y Marco Antonio Montes de Oca; en el 6 en que se publican adelantos de Renga; en el 8 en la sección especial "Poesía concreta: configuración/textos”; y en el 16 con los poemas del mexicano Ulises Carrión escritos al estilo de formularios a llenar. También se publicaron adelantos de Los hijos del limo en los números 26, 27 y 28, entre noviembre de 1973 y enero de 1974, y una reseña del mismo volumen, en el número 39, de diciembre de 1974, firmada por José Miguel de Oviedo.

7 En la versión de Obras completas, Paz agregó junto al nombre de Lezama Lima una llamada de nota a pie de página con el comentario siguiente: “También, ¿por qué no decirlo?, en varias más: ¿Águila o sol? (1950), Homenaje y profanaciones (1960), Blanco (1965), etcétera”. 
mágica del lenguaje: la ambigüedad. Me parece que ahora la palabra clave es indeterminación. Textos en movimiento. (12-3)

Intervención, indeterminación, todo apunta de nuevo hacia la noción de obra abierta y estructura -en el sentido expresado al final de Los hijos del limo- pues "lo que sobrevive de los libros” estaría identificado con el "principio invariante que es el fundamento de los cambios".

En “Poesía e historia: Laurel y nosotros”, Paz comenta que una antología que se propusiera abarcar la poesía publicada durante los cuarenta años siguientes tendría que comenzar poniendo al día las selecciones de Laurel. La mayoría de los poetas de Laurel, dice Paz, habían escrito lo mejor o más característico de su obra hacia 1940. Las excepciones, que detalla, son pocas: Juan Ramón Jiménez, Dámaso Alonso, Pablo Neruda y Jorge Luis Borges. La operación depuratoria parece formar un conjunto de antecesores, en esta antología hipotética, que preparan la entrada de la generación de ruptura-la de la vanguardia silenciosa- así como Tablada, López Velarde, Reyes y Torri forman el preámbulo de la ruptura definitiva con cualquier resabio del modernismo en Poesía en movimiento. En este punto de su comentario, Paz señala que la ruptura de 1940 es menos violenta que la de 1920, que no usó manifiestos ni actitudes públicas sino que fue emprendida silenciosamente por unos cuantos poetas aislados, y remite a sus observaciones de Los hijos del limo, con lo cual nos dice que después de ocho años continuaba encontrándolas válidas.

Más adelante, Paz se apoya en la mencionada Antología de la poesía hispanoamericana contemporánea (1914-1970), de José Olivio Jiménez, quien afirma que 1940 es el año divisorio, en que poetas nacidos a partir de 1910 comienzan a producir una nueva poesía "que intenta una penetración de la realidad, en busca de su dimensión última”. El resultado de esta tendencia es un "hermetismo expresivo casi total" cuyo representante más notable es Lezama Lima. Otra dirección es la de las “inquietudes de carácter existencial entrañable”. Paz hace las citas anteriores del "Prólogo" de Jiménez pero no muestra su complejidad e incluso omite que el representante de la dirección existencial es él mismo o que ambas direcciones están teñidas por el surrealismo. El diálogo de Jiménez con Paz en el "Prólogo" es intenso. Cita los libros El arco y la lira (1967) y Cuadrivio (1965) y el ensayo "Una de cal...” (1967). Por el lado de Paz, hay ciertas coincidencias con las caracterizaciones de las expresiones poéticas que rodean el agotamiento de las vanguardias en Los hijos del limo. Si se atiende a las fechas, cabría la posibilidad de que Paz, antes de publicar esta obra, hubiera tenido en sus manos la antología de Jiménez. El comentario de Paz continúa con el señalamiento de que la antología compendia exclusivamente poetas hispanoamericanos y sólo unos cuantos nacidos a partir de 1910, es decir, la promoción que produce la "nueva poesía”. Además de la observación ya referida acerca de las dos generaciones posteriores a la suya, concluye observando que "un autor que se propusiese hacer hoy una antología del último período (1940-1980), con el mismo rigor y la misma amplitud de Laurel, tendría que incluir a tres grupos o promociones poéticas. El hecho de que nadie lo haya intentado me asombra y entristece” (Obras II 771-2). ${ }^{8}$

8 En Obras II, Paz agrega el siguiente comentario al final del párrafo al que pertenece esta cita: “Dos recientes antologías han reparado esta omisión, una de ellas de Juan Gustavo Cobo Borda y otra de 
El período de vigencia del gusto poético de Laurel, 1920-1945, del cual Paz, como vimos, se deslinda, coincide en su fecha terminal con la propuesta de la vanguardia silenciosa. Es posible entonces sugerir que la nómina de esta última constituye un punto de arranque para el proyecto hipotético de una antología que cubriera los cuarenta años de producción poética hispanoamericana comprendidos entre 1940 y 1980. Ordenados conforme a su fecha de nacimiento, los poetas originalmente incluidos son: Enrique Molina (1910), José Lezama Lima (1910), Nicanor Parra (1914), Octavio Paz (1914), Alberto Girri (1919), Cintio Vitier (1921), Álvaro Mutis (1923), Roberto Juarroz (1925) y Jaime Sabines (1926). Un antecedente interesante es la lista que aparece en el artículo "Legítima defensa: Carlos Martínez Rivas” (fechado en 1954 y publicado en 1957), presentada por Paz como "signos y anuncios de una nueva época poética”:

En Cuba, el grupo Orígenes: Lezama Lima, Vitier, Eliseo Diego. En Perú, en torno a la desaparecida revista Las Moradas, animada por Westphalen y César Moro. En Buenos Aires, la poesía luminosa y fácil de Enrique Molina (fácil en el sentido en que son fáciles el crecer del árbol, la vegetación del mar o la sucesión de imágenes del sueño), el decir concentrado y ascético de Girri, el boscoso lenguaje -ora sombrío ora brillante- de Eduardo Lozano. En Chile, Nicanor Parra, Braulio Arenas, Anguita, Gonzalo Rojas... Y cerca de nosotros, en la pequeña Nicaragua, un grupo de poetas que recogen el ejemplo de Salomón de la Selva: Coronel Urtecho, el iniciado, que "si no ha creado muchos poemas, en cambio ha creado a varios poetas”; Joaquín Pasos, gran talento poético que antes de morir cantó la rebelión de las cosas, como en el Popol Vuh; Pablo Antonio Cuadra y tres jóvenes: Carlos Martínez Rivas, Ernesto Cardenal y Ernesto Mejía Sánchez. (Paz, Obras II:1125)

Es posible que un análisis detallado de los poetas y obras que Paz menciona permita confirmar o matizar las directrices que trazó para definir a la vanguardia silenciosa. Habría que revisar las opiniones que sobre cada uno de ellos plasmó en sus ensayos y artículos para ver qué grado de cohesión presentan, además de revisar la labor de selección que llevó a cabo en las publicaciones que dirigió: Plural y Vuelta. Quizá de esa manera se confirme que lo que parecía una mera intuición, y se encuentra disperso en su producción, tiene un carácter más orgánico y contribuye a esa difícil tarea que es tratar de dibujar el fin o las transformaciones definitivas de las vanguardias hispanoamericanas.

\footnotetext{
Julio Ortega. Ninguna de las dos incluye a los poetas españoles”. Ambas antologías son deudoras de la propuesta de Paz. La selección de Cobo Borda incluye poetas nacidos entre 1910 y 1939 y su prólogo es histórico y analítico, de una extensión considerable (54 páginas). Ofrece abundantes referencias entre las que se cuenta, específicamente, la de "Poesía e historia: Laurel y nosotros", y un elogioso reconocimiento a la contribución de Paz para descubrir un territorio poético aún no cartografiado, a través de sus múltiples ensayos y prólogos. La selección de Ortega incluye a poetas nacidos entre 1904 y 1951 y su breve prólogo (12 páginas) tiene un corte lírico, libre de referencias. Ortega explica que su antología no es de autores ni de textos sino de la lectura: "un selección de poesía cuyo sentido radica en la actividad del lector, en esa lectura que organiza los textos como un proyecto de su propia aventura y goce creadores” (3). No hay una referencia específica a la obra crítica de Paz pero en esto último se podría entender como un diálogo con lo expuesto en Poesía en movimiento.
} 
Borges, Jorge Luis. "Un caudaloso manifiesto de Breton”. El Hogar (2 diciembre 1938): 529-30.

Calinescu, Matei. Five Faces of Modernity. 2 ed. Durham: Duke UP, 1988.

Cobo Borda, Juan Jacobo, sel., pról. y notas. Antología de la poesía hispanoamericana. México: FCE, 1985.

Enzensberger, Hans Magnus. “Las aporías de la vanguardia”. Detalles. M. Angochev Millet, trad. 2 ed. Barcelona: Anagrama, 1985. 145-174.

Forster, Merlin H. “Latin American Vanguardismo: Chronology and Terminology”. Tradition and Renewal. Essays on Twentieth-Century Latin American Literature and Culture. Merlin H. Forster, ed. Urbana: U of Illinois P, 1975.

Jiménez, José Olivio, sel., pról. y notas. Antología de la poesía hispanoamericana contemporánea (1914-1970). 7 ed. Madrid: Alianza, 1984.

Ortega, Julio, sel., pról. y notas. Antología de la poesía hispanoamericana actual. México: Siglo XXI, 1987.

Osorio, Nelson, ed. Manifiestos, proclamas y polémicas de la vanguardia literaria hispanoamericana. Caracas: Ayacucho, 1988.

Paz, Octavio, El arco y la lira. México: FCE, 1983.

Los hijos del limo. Del romanticismo a la vanguardia [1974]. 2 ed. Barcelona: Seix Barral, 1989. La otra voz. Poesía y fin de siglo, Barcelona: Seix Barral, 1990. Obras completas 1. La casa de la presencia. Poesía e historia. 2 ed. México: FCE, 1994.

Obras completas 2. Generaciones y semblanzas. Dominio mexicano. 2 ed. México: FCE, 1994.

Obras completas II. Excursiones/Incursiones. Dominio extranjero. Fundación y disidencia. Dominio hispánico. 2 ed. Barcelona: Galaxia Gutenberg/Círculo de Lectores, 2000.

“Poesía e historia: Laurel y nosotros”. Obras completas II: 722-78.

Alí Chumacero, José Emilio Pacheco y Homero Aridjis, selecciones y notas. Poesía en movimiento. México 1915-1966 [1966]. 14 ed. México: Siglo XXI, 1980.

Schopf, Federico. Del vanguardismo a la antipoesía. Santiago: LOM, 2000.

Schwartz, Jorge, ed. Las vanguardias latinoamericanas. Textos programáticos y críticos. México: FCE, 2002.

Stanton, Anthony. “Tres antologías: la formulación del canon”. Inventores de tradición: ensayos sobre poesía mexicana moderna. México: FCE-El Colegio de México, 1998.

Verani, Hugo. Las vanguardias literarias en hispanoamérica. Roma: Bulzoni, 1986. 